\title{
Children of HIV positive haemophilic men
}

\author{
Eleanor Goldman, Christine Lee, Riva Miller, Peter Kernoff, Joanna Morris-Smith,
} Brent Taylor

\begin{abstract}
All 14 children who were conceived at the time their 12 haemophilic fathers were anti-HIV positive were shown to be HIV negative and to be healthy physically and mentally. Eleven of the 12 female partners have remained anti-HIV negative and one has seroconverted. Despite counselling it is likely that children will continue to be conceived by anti-HIV positive haemophiliacs.
\end{abstract}

(Arch Dis Child 1993;68:133-4)

Many haemophilic men have become infected with HIV after the administration of contaminated clotting factor concentrates. In a cohort of 111 haemophiliacs followed up at the Royal Free Hospital's haemophilia centre there was a wide range of age of seroconversion, 2-77 years with a median of 24 years. ${ }^{1}$ Thus haemophilic men and their partners may wish to have children and despite counselling pregnancies may be unplanned. This report describes the follow up of children conceived by anti-HIV positive haemophiliacs.

Royal Free Hospital and School of Medicine, London,

Haemophilia Centre

Eleanor Goldman

Christine Lee

Riva Miller

Peter Kernoff

Department of

Community Child Health

Joanna Morris-Smith

Brent Taylor

Correspondence to:

Dr Christine Lee,

Haemophilia Centre

Royal Free Hospital,

Pond Street,

Hampstead,

London NW3 2QG.

Accepted 11 August 1992

\section{Methods}

During 1983 and 1984 all haemophilic patients were told of the possible risk of HIV infection from blood products and all were advised to practise safer sex and use condoms as there were no diagnostic tests for HIV at that time. From 1985 onwards, when HIV testing was possible, couples were informed of the HIV status of the patient and of the risks of transmission to mother and child if they decided to have children. ${ }^{2}$ For those who had decided to have a child despite the risks ovulation kits were

Table 1 Details of children (all anti-HIV negative and p24 antigen negative)

\begin{tabular}{|c|c|c|c|c|c|c|}
\hline \multirow{2}{*}{$\begin{array}{l}\text { Child } \\
\text { No }\end{array}$} & \multirow{2}{*}{$\begin{array}{l}\text { Date of } \\
\text { conception }\end{array}$} & \multirow{2}{*}{$\begin{array}{l}\text { Birth } \\
\text { weight } \\
\text { (g) }\end{array}$} & \multirow{2}{*}{$\begin{array}{l}\text { Whether } \\
\text { breast fed } \\
\text { (time in } \\
\text { months) }\end{array}$} & \multicolumn{2}{|c|}{ Centiles (\%) } & \multirow{2}{*}{$\begin{array}{l}\text { Cognitive } \\
\text { function }\end{array}$} \\
\hline & & & & Height & Weight & \\
\hline $\begin{array}{r}1 \\
2 \\
3 \\
4 \\
5 \\
6 \\
7 \\
8 \\
9 \\
10 \\
11 \\
12 \\
13 \\
14\end{array}$ & $\begin{array}{l}\text { March } 1984 \\
\text { April } 1984 \\
\text { September } 1984 \\
\text { November } 1984 \\
\text { February } 1985 \\
\text { March } 1986 \\
\text { June } 1986 \\
\text { June } 1986 \\
\text { October } 1986 \\
\text { August } 1987 \\
\text { May } 1988 \\
\text { August } 1989 \\
\text { November } 1989 \\
\text { June } 1991\end{array}$ & $\begin{array}{l}4200 \\
3500 \\
3400 \\
3000 \\
3700 \\
2800 \\
3600 \\
3100 \\
3100 \\
2800 \\
2700 \\
3400 \\
2800 \\
2800\end{array}$ & $\begin{array}{l}\text { Yes (4) } \\
\text { No } \\
\text { Yes (4) } \\
\text { No } \\
\text { Yes (3) } \\
\text { Yes (3) } \\
\text { No } \\
\text { No } \\
\text { Yes (5) } \\
\text { No } \\
\text { No } \\
\text { Yes } \\
\text { Yes } \\
\text { Yes }\end{array}$ & $\begin{array}{l}90 \\
50 \\
25 \\
50 \\
50 \\
50 \\
50 \\
50 \\
50 \\
50 \\
50 \\
50 \\
50 \\
50\end{array}$ & $\begin{array}{l}90 \\
50 \\
50 \\
50 \\
50 \\
50 \\
50 \\
50 \\
50 \\
50 \\
50 \\
50 \\
50 \\
50\end{array}$ & $\begin{array}{r}112 \text { (MP) } \\
87 \text { (MP) } \\
133 \text { (MP) } \\
123 \text { (MP) } \\
128 \text { (MP) } \\
113 \text { (BMS) } \\
132 \text { (BMS) } \\
84 \text { (BMS) } \\
99 \text { (BMS) } \\
104 \text { (BMS) } \\
= \\
- \\
=\end{array}$ \\
\hline
\end{tabular}

$M P=$ Merrill Palmer scale of mental tests $=$ mean (SD) 100 (16). BMS = Bailey mental scale: mean (SD) 100 (16). provided and they were advised to continue using a condom at all times except at ovulation. The duration of seropositivity and stage of HIV disease of the father at the time of conception were assessed retrospectively from clincal records and the results of laboratory tests on stored serum samples. The anti-HIV status of female partners was assessed from 1985 onwards. Infants were seen soon after birth and then at yearly intervals. Physical development was measured by routine clinical examination including height and weight measurements. Ability and intelligence in relation to expected levels at any given age was measured using the Merrill Palmer scale of mental tests or the Bailey scales of infant development to assess their cognitive functioning. The children were all assessed in the presence of at least one parent during the course of the outpatient visit.

\section{Results}

Fourteen children were conceived at the time their 12 fathers were anti-HIV positive (table 1 ).

Five couples had conceived a child before the HIV antibody test was available and thus before the father's seropositivity was known (children $1-5$, table 1). The parents of child 3 chose to have a second child (child 9, table 1 ). The father of children 3 and 9 had not brought his wife for counselling and believed that having one unaffected child meant it was safe to have another.

The two fathers of children 2, 8, and 14 had not disclosed their haemophilia to their partners when entering into arranged marriages. The parents of children $6,7,8,10,11,13$, and 14 made a decision to have children despite the known risks. One couple occasionally had unprotected sex which resulted in an unplanned pregnancy. They did not want the pregnancy terminated and child 12 was born (table 1 ).

The children have been seen annually since January 1985. All the children were anti-HIV negative and p24 antigen negative and have remained so. The majority of the children have maintained heights and weights around the 50th centile (table 1), and all have been healthy and developmentally normal.

Tests of cognitive function showed eight children functioning above the average range. Two children ( 2 and 8 ), whose first language was not English, were in the low average range. Four babies, 11, 12, 13, and 14 have not been tested for cognitive function.

The details of the fathers at the time of conception when they were all p24 antigen negative and asymptomatic are shown in table 2 .

The father of child 1 developed AIDS with 
Table 2 Fathers' details at time of conception

\begin{tabular}{|c|c|c|c|}
\hline $\begin{array}{l}\text { Child } \\
\text { No }\end{array}$ & $\begin{array}{l}\text { Father's } \\
\text { age } \\
\text { (years) }\end{array}$ & $\begin{array}{l}\text { T4 lymphocyte } \\
\text { count } \\
\left(\times 10^{y} / l\right)\end{array}$ & $\begin{array}{l}\text { Length of HIV } \\
\text { seropositivity } \\
\text { (years) }\end{array}$ \\
\hline $\begin{array}{r}1 \\
2 \\
3 \\
4 \\
5 \\
6 \\
7 \\
8 \\
9 \\
10 \\
11 \\
12 \\
13 \\
14\end{array}$ & $\begin{array}{l}33 \cdot 8 \\
26 \cdot 7 \\
31 \cdot 8 \\
31 \cdot 1 \\
25 \cdot 3 \\
30 \cdot 1 \\
37 \cdot 7 \\
22 \cdot 8 \\
33.9 \\
26 \cdot 1 \\
25 \cdot 6 \\
28 \cdot 0 \\
25 \cdot 0 \\
27 \cdot 0\end{array}$ & $\begin{array}{l}\overline{0.6} \\
- \\
\overline{-} \\
0.27 \\
0.56 \\
0.36 \\
\overline{1.13} \\
0.94 \\
0.36 \\
0.40 \\
0.34\end{array}$ & $\begin{array}{r}2.0 \\
3.4 \\
0.9 \\
2.5 \\
1.0 \\
3.7 \\
3.5 \\
2.7 \\
3.0 \\
5.9 \\
3.5 \\
10.0 \\
6.0 \\
7.7\end{array}$ \\
\hline $\begin{array}{l}\text { Median } \\
\text { Range }\end{array}$ & $\begin{array}{l}28 \cdot 0 \\
22 \cdot 8-37 \cdot 7\end{array}$ & & $\begin{array}{l}3.0 \\
0.9-10 \cdot 0\end{array}$ \\
\hline
\end{tabular}

Pneumocystis carinii pneumonia in June 1988. He was well at the time of writing with a T4 lymphocyte count of $0.06 \times 10^{9} / 1$ and was on treatment with zidovudine and nebulised pentamidine as secondary prophylaxis against $P$ carinii pneumonia. The father of child 2 developed AIDS (with cerebral toxoplasmosis) in August 1991. Two haemophiliacs had two children, numbers 3 and 9, and numbers 8 and 14 respectively. The father of child 4 developed AIDS with cerebral toxoplasmosis in September 1988 and died of Mycobacterium avium intracellulare in February 1989. The father of child 6 developed AIDS with non-Hodgkin's lymphoma in December 1987 and died one year later in December 1988. The father of children 8 and 14 developed HIV related thrombocytopenia and was successfully treated by splenectomy in August 1988. All the remaining six fathers are asymptomatic. The father of child 12 is notable in that he was the first haemophiliac in the cohort to seroconvert after transfusion in August 1979. ${ }^{3}$

The mother of child 2 was found to be antiHIV positive when she was referred from another centre early in a second pregnancy, which she and her husband chose to have terminated. She had not previously been tested for HIV. The remaining 11 partners have tested anti-HIV negative.

\section{Discussion}

None of the 14 children in our study have shown any evidence of having acquired HIV infection. Although 11 of the 12 mothers were anti-HIV negative at the time of delivery and have remained so, we do not known when the mother of child 2 seroconverted. This suggests that the risk of HIV transmission directly through sperm must be low, if it exists at all. Certainly it has not been possible to find HIV DNA in sperm analysed by the polymerase chain reaction. ${ }^{4}$ Our observations appear to support the suggestion that purifying the sperm from infected men and using artificial insemination or in vitro fertilisation might provide a way for men infected with HIV to have children with minimal risk to wife and child. ${ }^{4}$

A study in the United States reported that despite intensive education and counselling regarding HIV transmission and prevention of transmission, fewer than half of the couples in which one member was a haemophiliac practise these preventative measures consistently. ${ }^{5}$ Thus it is likely that children will continue to be conceived by anti-HIV positive haemophiliacs despite the risk of HIV transmission to their wives and children. It is therefore important that such children are monitored not only to reassure them and their parents, but to provide information for other couples making decisions about childbearing.

1 Lee CA, Phillips AN, Elford J, Janossy G, Griffiths P, Kernoff P. Progression of HIV disease in a haemophilic cohort followed for 11 years and the effect of treatment. cohort followed for 11

2 Goldman $E$ Miller $R$, Lee CA Counselling HIV positive haemophilic men who wish to have children. $B M \mathcal{F}$ 1992; 304:829-30.

3 Lee CA, Webster A, Griffiths PD, Kernoff PBA. Symptomless HIV infection after more than ten years. Lancet 1990; 335:425-6.

4 Marx JL. Do sperm spread the AIDS virus? Science 1989; 245:30.

5 Ragni MV, Nimorwicz P. Human immunodeficiency virus transmission and hemophilia. Arch Intern Med 1989;149: 1379-80. 